\title{
Accounting for the mortality benefit of drug- eluting stents in percutaneous coronary intervention: a comparison of methods in a retrospective cohort study
}

\author{
Robert W Yeh ${ }^{1 *}$, Malini Chandra ${ }^{2}$, Charles E McCulloch ${ }^{3}$ and Alan S Go ${ }^{2}$
}

\begin{abstract}
Background: Drug-eluting stents (DES) reduce rates of restenosis compared with bare metal stents (BMS). A number of observational studies have also found lower rates of mortality and non-fatal myocardial infarction with DES compared with BMS, findings not observed in randomized clinical trials. In order to explore reasons for this discrepancy, we compared outcomes after percutaneous coronary intervention (PCI) with DES or BMS by multiple statistical methods.
\end{abstract}

Methods: We compared short-term rates of all-cause mortality and myocardial infarction for patients undergoing $\mathrm{PCl}$ with DES or BMS using propensity-score adjustment, propensity-score matching, and a stent-era comparison in a large, integrated health system between 1998 and 2007. For the propensity-score adjustment and stent era comparisons, we used multivariable logistic regression to assess the association of stent type with outcomes. We used McNemar's Chi-square test to compare outcomes for propensity-score matching.

Results: Between 1998 and 2007, 35,438 PCls with stenting were performed among health plan members (53.9\% DES and $46.1 \%$ BMS). After propensity-score adjustment, DES was associated with significantly lower rates of death at 30 days (OR 0.49, 95\% Cl $0.39-0.63, P<0.001)$ and one year (OR 0.58, 95\% Cl $0.49-0.68, P<0.001)$, and a lower rate of myocardial infarction at one year (OR $0.72,95 \% \mathrm{Cl} 0.59-0.87, P<0.001)$. Thirty day and one year mortality were also lower with DES after propensity-score matching. However, a stent era comparison, which eliminates potential confounding by indication, showed no difference in death or myocardial infarction for DES and BMS, similar to results from randomized trials.

Conclusions: Although propensity-score methods suggested a mortality benefit with DES, consistent with prior observational studies, a stent era comparison failed to support this conclusion. Unobserved factors influencing stent selection in observational studies likely account for the observed mortality benefit of DES not seen in randomized clinical trials.

\section{Background}

The comparison of alternative treatments has long been a primary mission of both randomized trials and observational studies. With the commitment of $\$ 1.1$ billion in support of comparative effectiveness research in the American Recovery and Reinvestment Act of 2009, the

\footnotetext{
* Correspondence: ryeh@partners.org

'Cardiology Division, GRB800, Department of Medicine, Massachusetts

General Hospital, Harvard Medical School, Boston, MA 02114, USA

Full list of author information is available at the end of the article
}

number of studies comparing different drugs, devices, techniques and systems will undoubtedly increase dramatically [1]. While randomized clinical trials are likely to remain the gold standard for comparing alternative treatments, observational studies should continue to have significant, if not leading, roles in comparative effectiveness research moving forward, particularly in light of recommendations to prioritize assessments of community-based interventions within populations traditionally underrepresented in clinical trials [2].

\section{C) Biomed Central}


However, observational studies are subject to a number of limitations, foremost among them the potential for unmeasured variables that confound results. While a number of methods directed at assessing causal effects and eliminating confounding have been developed, few clinical studies describe reasons for the specific choice of method used, and fewer present multiple methods to help corroborate findings[3,4].

Observational studies comparing drug-eluting stents (DES) and bare metal stents (BMS) for percutaneous coronary intervention (PCI) have consistently shown lower mortality and myocardial infarction associated with DES [5-20], findings not seen in randomized clinical trials [21-27]. We applied three common methods to compare DES to BMS within a large observational study population to: 1) determine whether mortality benefit for DES was observed in our study population and 2) to identify potential challenges to the application of these methods to compare treatments in the presence of strong treatment selection.

\section{Methods}

We conducted a retrospective dynamic cohort study within Kaiser Permanente of Northern California (KPNC), a large integrated healthcare delivery system caring for $>3.2$ million individuals that are broadly representative of the local surrounding and statewide population[28]. All health plan members aged 30 years and older between January 1998 and the end of December 2007 were considered eligible. The study was reviewed by the institutional review board of the Kaiser Division of Research, and requirement for informed consent was waived due to the nature of the study. From this cohort, we identified all PCI procedures using either DES or BMS based on relevant International Classification of Diseases, Ninth Revision, Clinical Modification (ICD-9-CM) and Current Procedural Terminology (CPT) codes that occurred within health plan and non-health plan hospitals [29]. Consecutive procedures occurring within 7 days of one another were considered part of the same clinical episode. Procedures in which both DES and BMS were used were excluded from the analysis.

\section{Patient characteristics and coexisting illnesses}

Patient demographic information was obtained from health plan electronic databases. Relevant ICD-9 or CPT codes found in hospital discharge databases during the eight years before the procedure date were used to identify prior cardiovascular disease including prior myocardial infarction, prior angina, prior PCI or coronary artery bypass graft (CABG) surgery, history of ischemic stroke and peripheral arterial disease. Prior chronic heart failure was determined based on a validated algorithm using information from hospitalization, outpatient and emergency department diagnostic codes[30].

Relevant data sources were searched for cardiovascular risk factors. Diabetes mellitus was identified from a validated longitudinal Diabetes Registry relying on inpatient and outpatient diabetes diagnoses, receipt of anti-diabetic therapies, and abnormal glycosylated hemoglobin or blood glucose levels [31]. Hypertension was based on serial ambulatory diagnoses or the combination of diagnoses and receipt of anti-hypertensive medications. Chronic lung disease, systemic malignancy, and history of gastrointestinal bleeding were determined based on validated methods [29-35]. The presence and severity of chronic kidney disease was ascertained using the abbreviated four-variable Modification of Diet in Renal Disease (MDRD) equation for estimated glomerular filtration rate based on most recent outpatient determination of serum creatinine within the previous 24 months before the year examined[33].

\section{Medication usage}

Prior observational studies comparing outcomes for DES and BMS have not included the chronic outpatient use of cardioprotective medications, an important potential confounder $[6,19,36]$. Outpatient medication use within 30 days before PCI was ascertained from health plan pharmacy records for therapies known to lower cardiovascular risk, including beta-blockers [37], angiotensinconverting enzyme (ACE) inhibitors or angiotensin receptor blockers (ARBs),[38] statins [39], and thienopyridines [40]. Outpatient warfarin use was also assessed. More than $90 \%$ of patients had a drug benefit that provided strong financial incentives to obtain medications from health plan pharmacies.

\section{Primary outcomes}

Death from any cause occurring within thirty days and one year after the procedure was identified from health plan administrative databases, proxy information, Social Security Administration vital status files, and California state death certificate information $[41,42]$. Subsequent hospitalized myocardial infarction based on ICD-9-CM codes (primary discharge diagnosis coded as 410.x1) within one year was also identified.

\section{Statistical analysis}

Three separate methods were used to compare outcomes after DES and BMS: 1) statistical adjustment based on propensity score decile, 2) propensity-score matching, and 3) a stent era comparison, in which outcomes before and after the introduction of DES in 2003 were compared. 


\section{Method 1: propensity-score adjustment}

Because patients were not eligible to receive DES until after April of 2003, only PCI procedures after this date were included in the propensity score methods. A nonparsimonious logistic regression model was used to generate propensity scores for the likelihood of receiving DES based on 23 demographic and clinical variables. Propensity score deciles were created, and logistic regression was performed modeling the association of DES with outcomes, adjusted for propensity score decile (categorical variable) as well as the complete set of patient covariates. To accommodate data from individuals who may have undergone multiple procedures during the study period, robust standard errors accounting for clustering by patient were used.

\section{Method 2: propensity-score matching}

In the second method, one-to-one nearest neighbor matching was performed to compare outcomes after DES and BMS in patients undergoing PCI after April 2003. Caliper width was set at 0.0001 using the STATA program psmatch2 (Leuven and Sianesi, 2003) [43]. Adequacy of the match was assessed by estimating the standardized differences between DES and BMS patients for all variables. Outcomes were compared between groups using the McNemar's Chi-square test for matched comparisons.

\section{Method 3: stent era comparison}

Because DES was not available before 2003 and from 2004 onward DES was used in the vast majority of cases, a comparison of outcomes of PCI prior to and after DES introduction serves as a useful surrogate for assessing the impact of DES (Figure 1) $[4,36,44]$. Procedures between January 1998 and March 2003 were assigned to the 'BMS era', while those between April 2003 and December 2007 were assigned to the 'DES era'. This variable would be expected to be strongly associated with treatment assignment, and less prone to unmeasured confounding by stent indication. Logistic regression was then performed to determine the association of stent era with outcomes, adjusted for all assessed covariates.

Analyses were performed using STATA (Stata Corp. 2008. Stata Statistical Software: Release 10, College Station, TX: StataCorp LP). A two-sided $P$ value of $<0.05$ was considered significant for all analyses.

\section{Results}

A total of 35,438 PCIs with stent placement between January 1998 and December 2007 were included. Of

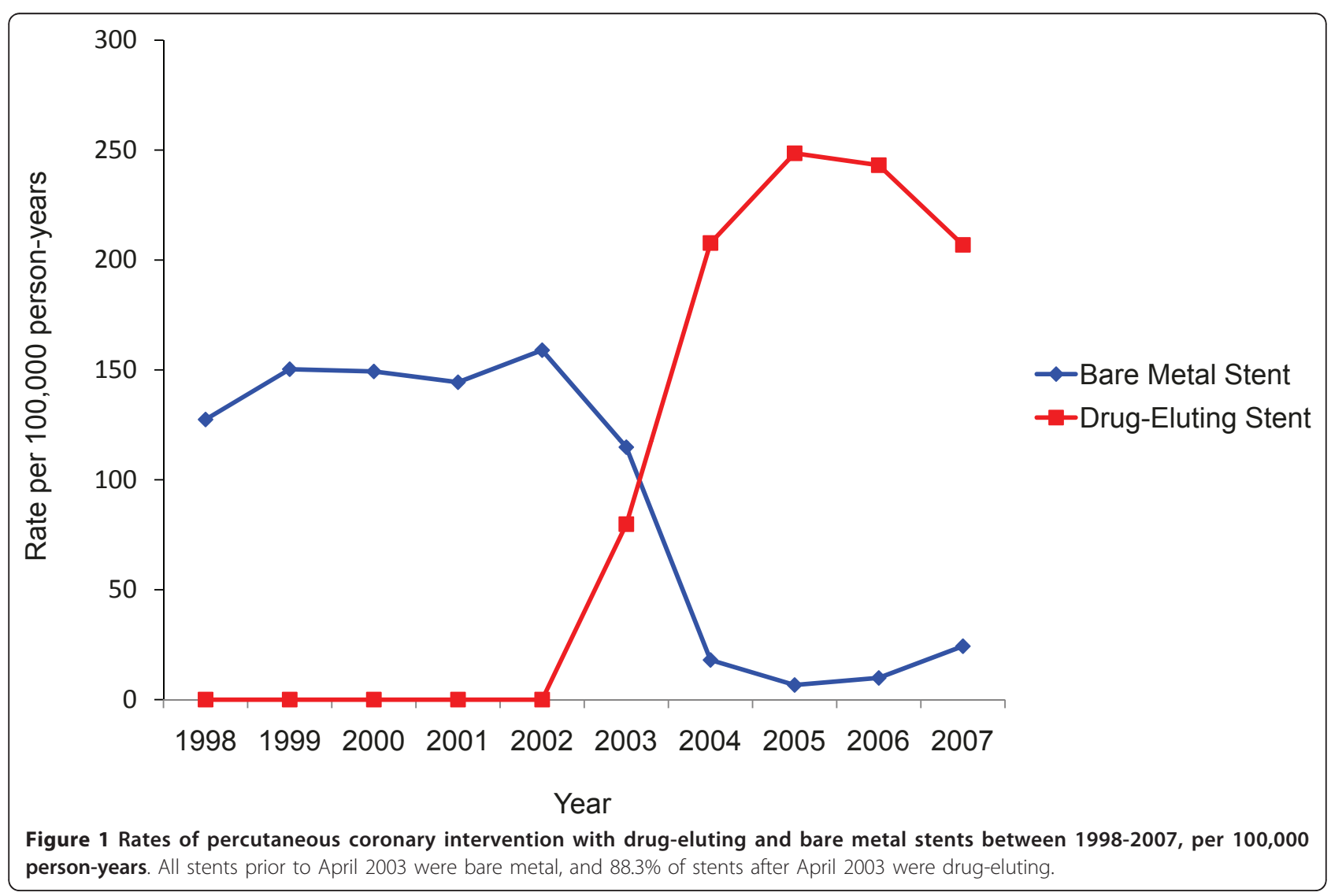


these, 19,103 (53.9\%) utilized DES and 16,335 (46.1\%) utilized BMS. Patients receiving DES were significantly different than those receiving BMS in nearly all baseline characteristics, including having significantly higher rates of hypertensions, diabetes, and congestive heart failure (Table 1). DES patients also had lower

Table 1 Characteristics of Patients Undergoing PCI by Stent Type, 1998-2007

\begin{tabular}{|c|c|c|c|}
\hline & $\begin{array}{l}\text { Drug- } \\
\text { Eluting } \\
\text { Stent }\end{array}$ & $\begin{array}{l}\text { Bare } \\
\text { Metal } \\
\text { Stent }\end{array}$ & $P$ Value \\
\hline $\mathbf{N}$ & 19,103 & 16,335 & \\
\hline Age (years) & 64.1 & 63.2 & $<0.001$ \\
\hline Male Sex (\%) & 70.8 & 70.6 & 0.72 \\
\hline Race/Ethnicity (\%) & & & $<0.001$ \\
\hline Asian & 9.8 & 7.0 & \\
\hline Black & 5.3 & 5.3 & \\
\hline Hispanic & 9.4 & 8.4 & \\
\hline White, non-Hispanic & 65.8 & 72.1 & \\
\hline Other & 9.7 & 7.3 & \\
\hline \multicolumn{4}{|l|}{ Comorbidities (\%) } \\
\hline Diabetes & 33.8 & 26.2 & $<0.001$ \\
\hline Hypertension & 68.5 & 49.6 & $<0.001$ \\
\hline Prior Ml & 13.0 & 11.1 & $<0.001$ \\
\hline PCl Indication: & & & $<0.001$ \\
\hline STEMI & 16.0 & 27.5 & \\
\hline NSTEMI & 28.0 & 19.3 & \\
\hline Stable or unstable angina & 57.3 & 54.8 & \\
\hline Prior $\mathrm{PCl}$ & 19.1 & 14.1 & $<0.001$ \\
\hline Prior CABG & 5.7 & 5.3 & 0.12 \\
\hline Congestive Heart Failure & 4.6 & 3.4 & $<0.001$ \\
\hline Prior Stroke & 1.6 & 1.2 & 0.005 \\
\hline Peripheral Arterial Disease & 4.3 & 3.3 & $<0.001$ \\
\hline Glomerular Filtration Rate & & & $<0.001$ \\
\hline$>90$ & 15.0 & 16.2 & \\
\hline $60-89$ & 39.7 & 33.4 & \\
\hline $30-59$ & 21.5 & 15.2 & \\
\hline $15-30$ & 1.9 & 1.3 & \\
\hline$<15$ or $\mathrm{HD}$ & 0.7 & 0.5 & \\
\hline Unknown & 21.1 & 33.3 & \\
\hline Systemic Malignancy & 5.7 & 5.8 & 0.75 \\
\hline Prior Gastrointestinal Bleeding & 2.3 & 1.8 & $<0.001$ \\
\hline Chronic Lung Disease & 18.3 & 21.9 & $<0.001$ \\
\hline \multicolumn{4}{|l|}{ Medications } \\
\hline$\beta$-Blockers & 50.0 & 40.1 & $<0.001$ \\
\hline Clopidogrel & 12.7 & 6.3 & $<0.001$ \\
\hline Statin & 51.7 & 34.8 & $<0.001$ \\
\hline ACE-I/ARB & 41.9 & 27.8 & $<0.001$ \\
\hline Warfarin & 3.8 & 3.0 & $<0.001$ \\
\hline
\end{tabular}

Abbreviations: MI, myocardial infarction; STEMI, ST-elevation myocardial infarction; NSTEMI, non-ST-elevation myocardial infarction; $\mathrm{PCl}$, percutaneous coronary intervention; $\mathrm{CABG}$, coronary artery bypass graft surgery. rates of presentation with ST-elevation myocardial infarction within 30 days prior to $\mathrm{PCI}$, and were more likely to be receiving outpatient cardioprotective medications including statins, beta-blockers and thienopyridines. Crude-mortality was significantly higher at thirty days $(2.2 \%$ versus $1.6 \%, P<.001)$ and one year $(5.1 \%$ versus $4.6 \%, P=0.04)$ after PCI with BMS compared to DES. The rate of myocardial infarction at one year was $4.7 \%$ after BMS and $4.3 \%$ after DES $(P=0.06)$.

Patients receiving BMS after April 2003 were markedly different than those receiving BMS before April 2003, having higher rates of hypertension $(65.0 \%$ versus $46.8 \%, P<0.001)$, congestive heart failure $(4.3 \%$ versus $3.2 \%, P=0.008)$, prior PCI $(9.3 \%$ versus $5.6 \%, P<$ $0.001)$, systemic malignancy $(9.3 \%$ versus $5.2 \%, P<$ 0.001 ) and prior gastrointestinal bleeding requiring hospitalization (3.0\% versus $1.7 \%, P<0.001)$. Crude-mortality at thirty days and one year and myocardial infarction at one year after PCI were significantly higher in patients receiving BMS after April 2003 compared those receiving BMS before 2003 (Figure 2).

\section{Association between stent type and outcomes by analytical method \\ After propensity-score adjustment, DES was associated} with significantly lower mortality at thirty days (OR $0.49,95 \%$ CI $0.39-0.63, P<0.001$ ) and one year (OR $0.58,95 \%$ CI $0.49-0.68, P<0.001)$, as well as a lower rate of myocardial infarction at one year (OR 0.72, 95\% CI $0.59-0.87, P<0.001)$. After $1: 1$ propensity-score matching $(\mathrm{n}=4,126)$, DES was again associated with significantly lower mortality at thirty days (OR 0.55, 95\% CI $0.35-0.85, P=0.005$ ), and at one year (OR 0.70, $95 \%$ CI $0.52-0.92, P=0.01)$. Myocardial infarction at one year was similar (OR 0.94, 95\% CI $0.71-1.25, P=$ 0.67). All standardized differences between groups were $<10 \%$, suggesting an adequate match (Table 2 ). In the stent era comparison, no differences in mortality were seen when comparing the DES era versus BMS era at thirty days (OR $0.92,95 \%$ CI $0.78-1.10, P=0.39$ ) or one year $(0.92,95 \%$ CI $0.82-1.02, P=0.12)$, or in the rate of myocardial infarction at one year (OR 0.92, 0.82 - 1.03, $P=0.16$ ) (Figure 3).

\section{Discussion}

We have shown that after the introduction of drug-eluting stents, bare metal stents were reserved for patients with significant comorbidities and high mortality rates. Commonly used propensity-score methods continued to suggest a mortality benefit to DES, while a stent era comparison showed no significant differences in all outcomes for DES and BMS, similar to results from randomized clinical trials. 


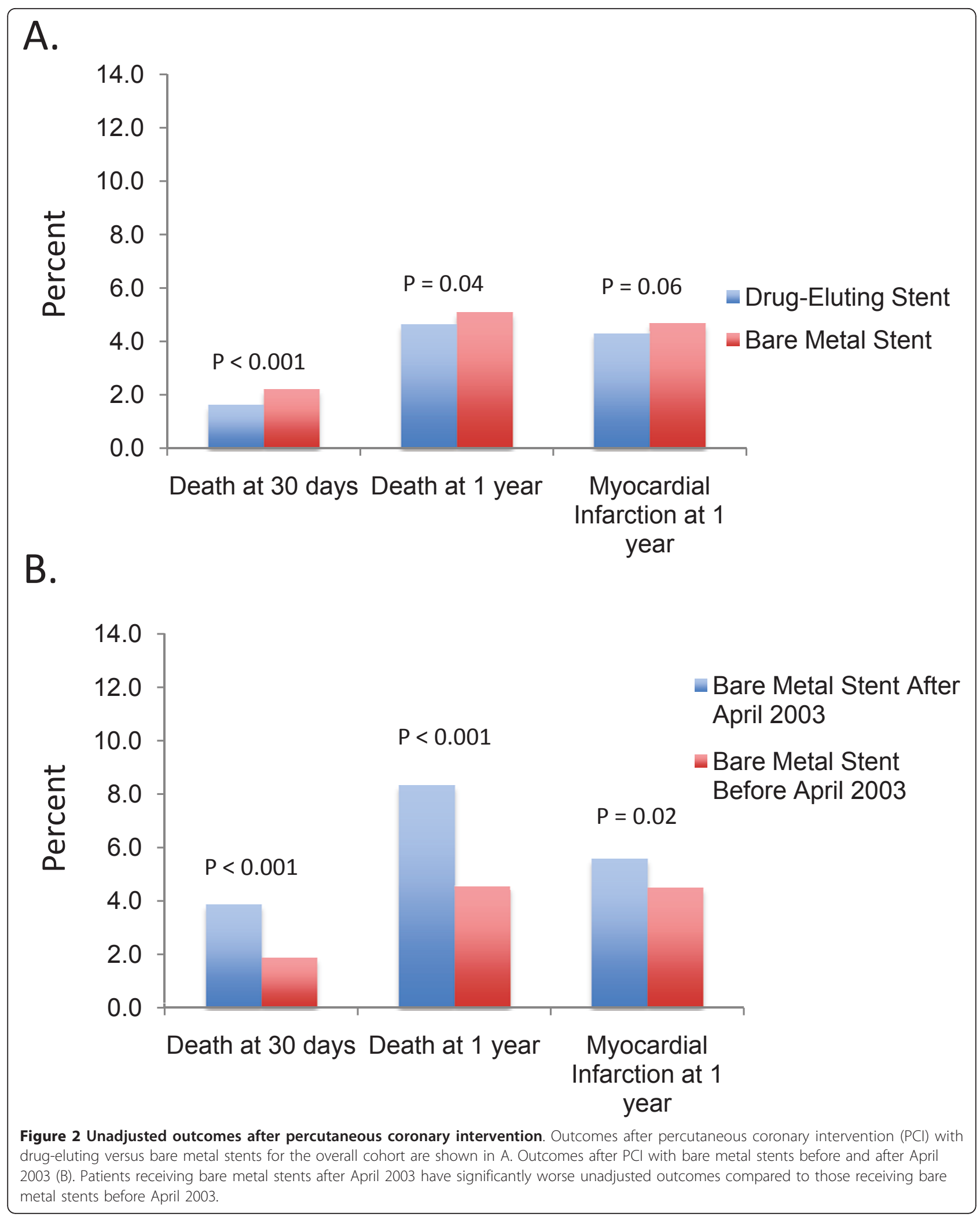


Table 2 Standardized Differences Between BMS and DES Patients Before and After Matching, April 1, 2003 December 31, 2007

\begin{tabular}{|c|c|c|}
\hline$N$ & $\begin{array}{c}\text { Standardized } \\
\text { Difference Prior to } \\
\text { Match } \\
\text { (2,518 BMS, 19,101 } \\
\text { DES) }\end{array}$ & $\begin{array}{c}\text { Standardized } \\
\text { Difference Post } \\
\text { Match } \\
\text { (2,063 BMS, } 2,063 \\
\text { DES) }\end{array}$ \\
\hline Age (years) & -8.3 & 1.9 \\
\hline Male Sex (\%) & -1.7 & -6.2 \\
\hline Race/Ethnicity & -11.3 & -5.8 \\
\hline \multicolumn{3}{|l|}{ Comorbidities (\%) } \\
\hline Diabetes & 9.1 & 3.5 \\
\hline Hypertension & 7.5 & -3.2 \\
\hline Prior Ml & 2.7 & 4.7 \\
\hline PCI Indication: & -21.6 & 0.2 \\
\hline Prior $\mathrm{PCl}$ & 6.1 & 6.1 \\
\hline Prior CABG & 2.5 & 2.5 \\
\hline $\begin{array}{l}\text { Congestive } \\
\text { Heart Failure }\end{array}$ & 3.8 & 3.8 \\
\hline Prior Stroke & 0.0 & 0.0 \\
\hline $\begin{array}{l}\text { Peripheral } \\
\text { Arterial Disease }\end{array}$ & 1.9 & 1.9 \\
\hline $\begin{array}{l}\text { Glomerular } \\
\text { Filtration Rate }\end{array}$ & 0.3 & 0.3 \\
\hline $\begin{array}{l}\text { Systemic } \\
\text { Malignancy }\end{array}$ & -13.4 & 0.4 \\
\hline $\begin{array}{l}\text { Prior } \\
\text { Gastrointestinal } \\
\text { Bleeding }\end{array}$ & -4.2 & -0.6 \\
\hline $\begin{array}{l}\text { Chronic Lung } \\
\text { Disease }\end{array}$ & -0.3 & 7.8 \\
\hline \multicolumn{3}{|l|}{ Medications } \\
\hline$\beta$-Blockers & 11.9 & -1.1 \\
\hline Clopidogrel & 8.9 & 3.4 \\
\hline Statin & 12.3 & 5.3 \\
\hline ACE-I/ARB & 9.2 & 4.1 \\
\hline Warfarin & 1.0 & 3.1 \\
\hline
\end{tabular}

Abbreviations: $\mathrm{Ml}$, myocardial infarction; $\mathrm{PCl}$, percutaneous coronary intervention; $\mathrm{CABG}$, coronary artery bypass graft surgery.

A number of prior observational studies comparing DES to BMS have suggested reductions in mortality and myocardial infarction associated with DES, the majority of which have utilized propensity-score methods to mitigate potential confounding [5-20]. However, data from randomized trials have not corroborated these findings [21-27]. In a meta-analysis of 22 randomized trials and 34 observational studies, Kirtane et al found no differences in mortality or myocardial infarction in randomized trials, but consistent reductions for both outcomes in observational studies, and attributed these differences, at least in part, to residual confounding by unmeasured differences between patients receiving BMS and DES [23]. Our results are consistent with this conclusion. In our cohort, patients who received BMS after April 2003 had significantly greater comorbidities and unadjusted death and myocardial infarction rates compared to patients who received BMS before this date, suggesting that physicians selectively reserved BMS for a sicker population of patients after DES was introduced. While propensity-score adjustment and matching both attempt to account for such differences, they only account for variables that are assessed. In the presence of such a high degree of patient selection, any residual confounding in this case is likely to lead to the appearance of improved outcomes with DES, as was seen in this study. While propensity scores have been put forward as a method which overcomes some of the limitations of traditional logistic regression, they do not address a primary threat to the validity of such studies - unmeasured confounding.

A comparison of the BMS era (100\% BMS) to the DES era (88.3\% DES) as a surrogate for a BMS-DES comparison eliminates the unwanted influence of patient selection [45]. Consistent with this, the stent era comparison showed no differences in mortality or myocardial infarction between BMS and DES, most closely approximating results seen in randomized trials. However, because such an analysis compares patients undergoing PCI at two different times, important secular trends may have influenced the results. For example, comparisons of stent eras in the Medicare population and in the New York PCI Registry both suggested lower rates of myocardial infarction in the DES era compared to BMS era $[36,44]$. However, neither study adjusted for differences in the use of outpatient medications such as statins and beta-blockers, which have increasingly been used in patients with coronary disease over time [46]. In this study, we found significantly higher rates of use of beta blockers, statins, angiotensin-converting enzyme inhibitors, and thienopyridines in the DES era. After accounting for these and other secular trends, no differences in myocardial infarction were observed between DES and BMS patients.

A number of circumstances specific to stent use allowed for the critical examination of these analytical methods. First, the rapid uptake of DES over BMS created a natural experiment allowing use of a stent era comparison. Second, because a large number of patients from randomized clinical trials comparing DES with BMS have been performed, these studies help provide an estimate of the 'truth.' However, in other examples in which the questions of interest may be less well studied, there could be much greater difficulty interpreting disparate results. 


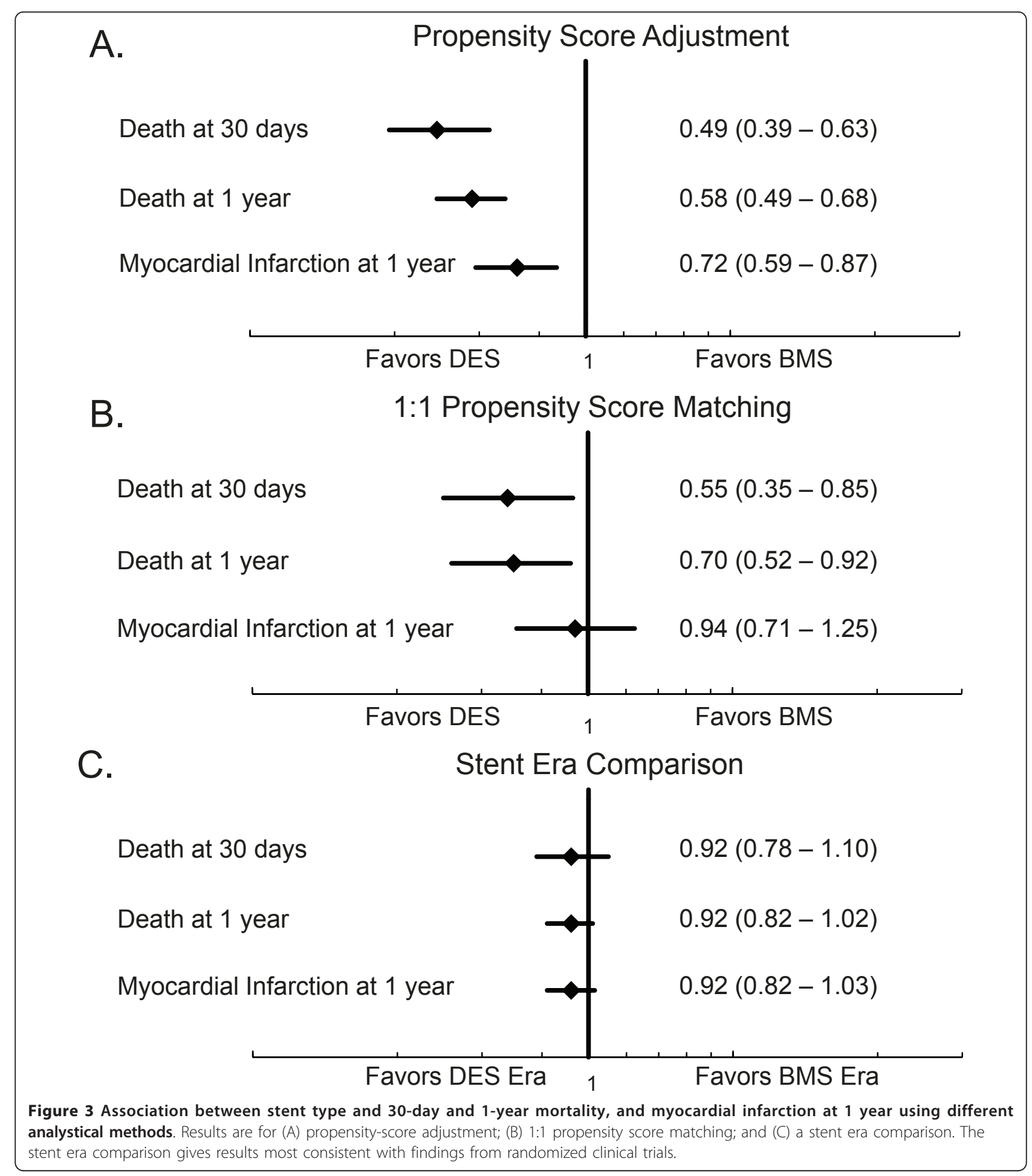

\section{Conclusions}

In summary, we have compared outcomes after PCI with either DES or BMS, using three commonly used methods of adjustment in observational studies. Large baseline differences in BMS and DES groups suggested strong treatment selection, which were incompletely adjusted for by propensity-score methods. In the presence of such treatment selection, alternative methods of analysis of observational data should be considered. 


\section{Acknowledgements and funding}

No additional acknowledgements.

This work was funded by institutional funds from the Massachusetts General Hospital and Kaiser Permanente of Northern California.

\section{List of abbreviations}

ACE: angiotensin-converting enzyme; ARBs: angiotensin receptor blockers; BMS: bare metal stents; CABG: coronary artery bypass graft; CPT: Current Procedural Terminology; DES: drug-eluting stents; ICD-9-CM: International Classification of Diseases: Ninth Edition: Clinical Modification; KPNC: Kaiser Permanente of Northern California; MDRD: modification of diet in renal disease; $\mathrm{PCl}$ : percutaneous coronary intervention.

\section{Author details}

${ }^{1}$ Cardiology Division, GRB800, Department of Medicine, Massachusetts General Hospital, Harvard Medical School, Boston, MA 02114, USA. ${ }^{2}$ Division of Research, Kaiser Permanente of Northern California, 2000 Broadway Street, 3rdFloor, Oakland, CA 94612, USA. ${ }^{3}$ Division of Biostatistics, Department of Epidemiology and Biostatistics, University of California, San Francisco, 185 Berry Street, Suite 5700, San Francisco, CA 94107, USA.

\section{Authors' contributions}

RWY conceived of the original idea for the study, conducted statistical analyses, and drafted the manuscript. MC assisted with analysis of the data and critically reviewed the manuscript. CEC advised on biostatistical methodology of the study and provided critical revisions of the manuscript. ASG supervised in the conception and design of the study and provided critical revisions of the manuscript. All authors read and approved the final manuscript.

\section{Competing interests}

The authors declare that they have no competing interests.

Received: 20 April 2011 Accepted: 24 June 2011

Published: 24 June 2011

\section{References}

1. The American Recovery and Reinvestment Act of 2009. H.R.1.ENR. [http://www.recovery.gov/About/Pages/The_Act.aspx], (Accessed July 4, 2011).

2. Conway PH, Clancy C: Comparative-effectiveness research - implications of the federal Coordinating Council's Report. N Engl J Med 2009, 361:328-330

3. Rubin DB: Estimating causal effects from large data sets using propensity scores. Ann Intern Med 1997, 127:757-763.

4. Mauri L, Normand SL: Studies of drug-eluting stents: to each his own? Circulation 2008, 117:2047-2050.

5. Mauri L, Silbaugh TS, Wolf RE, Zelevinsky K, Lovett A, Zhou Z, Resnic FS, Normand SL: Long-term clinical outcomes after drug-eluting and baremetal stenting in Massachusetts. Circulation 2008, 118:1817-1827.

6. Mauri L, Silbaugh TS, Garg P, Wolf RE, Zelevinsky K, Lovett A, Varma MR, Zhou Z, Normand SL: Drug-eluting or bare-metal stents for acute myocardial infarction. N Engl J Med 2008, 359:1330-1342.

7. Garg P, Normand SL, Silbaugh TS, Wolf RE, Zelevinsky K, Lovett A, Varma MR, Zhou Z, Mauri L: Drug-eluting or bare-metal stenting in patients with diabetes mellitus: results from the Massachusetts Data Analysis Center Registry. Circulation 2008, 118:2277-2285, 2277p following 2285.

8. Alahmar AE, Grayson AD, Andron M, Egred M, Roberts ED, Patel B, Moore RK, Albouaini K, Jackson M, Perry RA: Reduction in mortality and target-lesion revascularisation at 2 years: a comparison between drugeluting stents and conventional bare-metal stents in the "real world". Int J Cardiol 2009, 132:398-404

9. Applegate RJ, Sacrinty M, Kutcher M, Santos R, Gandhi S, Little W: Late outcomes of drug-eluting versus bare metal stents in saphenous vein grafts: propensity score analysis. Catheter Cardiovasc Interv 2008, 72:7-12.
10. Applegate RJ, Sacrinty MT, Kutcher MA, Baki TT, Gandhi SK, Santos RM, Little WC: Comparison of drug-eluting versus bare metal stents on later frequency of acute myocardial infarction and death. Am J Cardiol 2007, 99:333-338.

11. Brodie BR, Stuckey T, Downey W, Humphrey A, Nussbaum M, Laurent S, Bradshaw B, Metzger C, Hermiller J, Juk S, Cheek B, Duffy P, Simonton CA: Outcomes with drug-eluting stents versus bare metal stents in acute STelevation myocardial infarction: results from the Strategic Transcatheter Evaluation of New Therapies (STENT) Group. Catheter Cardiovasc Interv 2008, 72:893-900.

12. Gurvitch R, Lefkovits J, Warren RJ, Duffy SJ, Clark DJ, Eccleston D, Yan BP, Reid C, Brennan A, Andrianopoulos N, Ajani AE: Clinical outcomes of drugeluting stent use in patients with ST elevation myocardial infarction. Int J Cardiol 2010, 143:283-288.

13. Ko DT, Chiu M, Guo H, Austin PC, Goeree R, Cohen E, Labinaz M, Tu JV: Safety and effectiveness of drug-eluting and bare-metal stents for patients with off- and on-label indications. J Am Coll Cardiol 2009, 53:1773-1782.

14. Ortolani P, Balducelli M, Marzaroli P, Piovaccari G, Menozzi A, Guiducci V, Sangiorgio P, Tarantino F, Geraci G, Castriota F, Tondi S, Saia F, Cooke RM, Guastaroba P, Grilli R, Marzocchi A, Maresta A: Two-year clinical outcomes with drug-eluting stents for diabetic patients with de novo coronary lesions: results from a real-world multicenter registry. Circulation 2008, 117:923-930.

15. Palmerini T, Marzocchi A, Tamburino C, Sheiban I, Margheri M, Vecchi G, Sangiorgi G, Santarelli A, Bartorelli A, Briguori C, Vignali L, Di Pede F, Ramondo A, Inglese L, De Carlo M, Bolognese L, Benassi A, Palmieri C, Filippone V, Sangiorgi D, De Servi S: Two-year clinical outcome with drugeluting stents versus bare-metal stents in a real-world registry of unprotected left main coronary artery stenosis from the Italian Society of Invasive Cardiology. Am J Cardiol 2008, 102:1463-1468.

16. Roy $P$, Buch $A N$, Javaid A, Okabe $T$, Raya $V$, Pinto Slottow $T L$, Steinberg DH, Smith K, Xue Z, Gevorkian N, Satler LF, Kent KM, Suddath WO, Pichard AD, Lindsay J, Waksman R: Impact of "off-label" utilization of drug-eluting stents on clinical outcomes in patients undergoing percutaneous coronary intervention. Am J Cardiol 2008, 101:293-299.

17. Ruiz-Nodar JM, Marin F, Sanchez-Paya J, Hurtado JA, Valencia-Martin J, Manzano-Fernandez S, Roldan V, Perez-Andreu V, Sogorb F, Valdes M, Lip GY: Efficacy and safety of drug-eluting stent use in patients with atrial fibrillation. Eur Heart J 2009, 30:932-939.

18. Shishehbor MH, Goel SS, Kapadia SR, Bhatt DL, Kelly P, Raymond RE, Galla JM, Brener SJ, Whitlow PL, Ellis SG: Long-term impact of drug-eluting stents versus bare-metal stents on all-cause mortality. J Am Coll Cardiol 2008, 52:1041-1048.

19. Tu JV, Bowen J, Chiu M, Ko DT, Austin PC, He Y, Hopkins R, Tarride JE, Blackhouse G, Lazzam C, Cohen EA, Goeree R: Effectiveness and safety of drug-eluting stents in Ontario. N Engl J Med 2007, 357:1393-1402.

20. Douglas PS, Brennan JM, Anstrom KJ, Sedrakyan A, Eisenstein EL, Haque G, Dai D, Kong DF, Hammill B, Curtis L, Matchar D, Brindis R, Peterson ED: Clinical effectiveness of coronary stents in elderly persons: results from 262,700 Medicare patients in the American College of CardiologyNational Cardiovascular Data Registry. J Am Coll Cardiol 2009, 53:1629-1641.

21. Spaulding C, Daemen J, Boersma E, Cutlip DE, Serruys PW: A pooled analysis of data comparing sirolimus-eluting stents with bare-metal stents. N Engl J Med 2007, 356:989-997.

22. Spaulding C, Henry P, Teiger E, Beatt K, Bramucci E, Carrie D, Slama MS, Merkely B, Erglis A, Margheri M, Varenne O, Cebrian A, Stoll HP, Snead DB, Bode C: Sirolimus-eluting versus uncoated stents in acute myocardial infarction. N Engl J Med 2006, 355:1093-1104.

23. Kirtane AJ, Gupta A, lyengar S, Moses JW, Leon MB, Applegate R, Brodie B, Hannan E, Harjai K, Jensen LO, Park SJ, Perry R, Racz M, Saia F, Tu JV, Waksman R, Lansky AJ, Mehran R, Stone GW: Safety and efficacy of drugeluting and bare metal stents: comprehensive meta-analysis of randomized trials and observational studies. Circulation 2009, 119:3198-3206.

24. Kastrati A, Mehilli J, Pache J, Kaiser C, Valgimigli M, Kelbaek H, Menichelli M, Sabate M, Suttorp MJ, Baumgart D, Seyfarth M, Pfisterer ME, Schömig A: Analysis of 14 trials comparing sirolimus-eluting stents with bare-metal stents. N Engl J Med 2007, 356:1030-1039. 
25. Valgimigli M, Campo G, Arcozzi C, Malagutti P, Carletti R, Ferrari F, Barbieri D, Parrinello G, Percoco G, Ferrari R: Two-year clinical follow-up after sirolimus-eluting versus bare-metal stent implantation assisted by systematic glycoprotein IIb/Illa Inhibitor Infusion in patients with myocardial infarction: results from the STRATEGY study. J Am Coll Cardiol 2007, 50:138-145.

26. Pache J, Dibra A, Mehilli J, Dirschinger J, Schomig A, Kastrati A: Drugeluting stents compared with thin-strut bare stents for the reduction of restenosis: a prospective, randomized trial. Eur Heart J 2005, 26:1262-1268.

27. Morice MC, Serruys PW, Barragan P, Bode C, Van Es GA, Stoll HP, Snead D, Mauri L, Cutlip DE, Sousa E: Long-term clinical outcomes with sirolimuseluting coronary stents: five-year results of the RAVEL trial. J Am Coll Cardiol 2007, 50:1299-1304.

28. Krieger $\mathrm{N}$ : Overcoming the absence of socioeconomic data in medical records: validation and application of a census-based methodology. Am J Public Health 1992, 82:703-710.

29. Go AS, Chertow GM, Fan D, McCulloch CE, Hsu CY: Chronic kidney disease and the risks of death, cardiovascular events, and hospitalization. $N$ Engl $J$ Med 2004, 351:1296-1305.

30. Go AS, Lee WY, Yang J, Lo JC, Gurwitz JH: Statin therapy and risks for death and hospitalization in chronic heart failure. JAMA 2006, 296:2105-2111.

31. Selby JV, Ray GT, Zhang D, Colby CJ: Excess costs of medical care for patients with diabetes in a managed care population. Diabetes Care 1997, 20:1396-1402.

32. Executive Summary of The Third Report of The National Cholesterol Education Program (NCEP) Expert Panel on Detection, Evaluation, And Treatment of High Blood Cholesterol In Adults (Adult Treatment Panel III). JAMA 2001, 285:2486-2497.

33. Levey AS, Coresh J, Greene T, Stevens LA, Zhang YL, Hendriksen S, Kusek JW, Van Lente F: Using standardized serum creatinine values in the modification of diet in renal disease study equation for estimating glomerular filtration rate. Ann Intern Med 2006, 145:247-254.

34. K/DOQI Clinical Practice Guidelines for Chronic Kidney Disease: evaluation, classification, and stratification. Am J Kidney Dis 2002, 39: S1-246.

35. Fireman BH, Fehrenbacher L, Gruskin EP, Ray GT: Cost of care for patients in cancer clinical trials. J Nat/ Cancer Inst 2000, 92:136-142.

36. Hannan EL, Racz M, Holmes DR, Walford G, Sharma S, Katz S, Jones RH, King SB: Comparison of coronary artery stenting outcomes in the eras before and after the introduction of drug-eluting stents. Circulation 2008, 117:2071-2078.

37. The beta-blocker heart attack trial. beta-Blocker Heart Attack Study Group. JAMA 1981, 246:2073-2074.

38. Yusuf S, Sleight P, Pogue J, Bosch J, Davies R, Dagenais G: Effects of an angiotensin-converting-enzyme inhibitor, ramipril, on cardiovascular events in high-risk patients. The Heart Outcomes Prevention Evaluation Study Investigators. N Engl J Med 2000, 342:145-153.

39. Randomised trial of cholesterol lowering in 4444 patients with coronary heart disease: the Scandinavian Simvastatin Survival Study (4S). Lancet 1994, 344:1383-1389.

40. Bhatt DL, Fox KA, Hacke W, Berger PB, Black HR, Boden WE, Cacoub P, Cohen EA, Creager MA, Easton JD, Flather MD, Haffner SM, Hamm CW, Hankey GJ, Johnston SC, Mak KH, Mas JL, Montalescot G, Pearson TA, Steg PG, Steinhubl SR, Weber MA, Brennan DM, Fabry-Ribaudo L, Booth J, Topol EJ, CHARISMA Investigators: Clopidogrel and aspirin versus aspirin alone for the prevention of atherothrombotic events. N Engl J Med 2006, 354:1706-1717.

41. Newman TB, Brown AN: Use of commercial record linkage software and vital statistics to identify patient deaths. J Am Med Inform Assoc 1997, 4:233-237.

42. Arellano MG, Petersen GR, Petitti DB, Smith RE: The California Automated Mortality Linkage System (CAMLIS). Am J Public Health 1984, 74:1324-1330.

43. Austin PC: Some methods of propensity-score matching had superior performance to others: results of an empirical investigation and Monte Carlo simulations. Biom J 2009, 51:171-184.

44. Malenka DJ, Kaplan AV, Lucas FL, Sharp SM, Skinner JS: Outcomes following coronary stenting in the era of bare-metal vs the era of drugeluting stents. JAMA 2008, 299:2868-2876.

45. Normand SL: Some old and some new statistical tools for outcomes research. Circulation 2008, 118:872-884.
46. Yeh RW, Sidney S, Chandra M, Sorel M, Selby JV, Go AS: Population trends in the incidence and outcomes of acute myocardial infarction. $N$ Engl J Med 362:2155-2165.

\section{Pre-publication history}

The pre-publication history for this paper can be accessed here: http://www.biomedcentral.com/1741-7015/9/78/prepub

doi:10.1186/1741-7015-9-78

Cite this article as: Yeh et al:: Accounting for the mortality benefit of drug-eluting stents in percutaneous coronary intervention: a comparison of methods in a retrospective cohort study. BMC Medicine 2011 9:78.

\section{Submit your next manuscript to BioMed Central and take full advantage of:}

- Convenient online submission

- Thorough peer review

- No space constraints or color figure charges

- Immediate publication on acceptance

- Inclusion in PubMed, CAS, Scopus and Google Scholar

- Research which is freely available for redistribution 